\title{
Vitamin C improves microvascular reactivity and peripheral tissue perfusion in septic shock patients
}

\author{
Jean-Rémi Lavillegrand ${ }^{1,2}$, Lisa Raia1 ${ }^{1}$, Tomas Urbina ${ }^{1,2}$, Geoffroy Hariri ${ }^{1,2}$, Paul Gabarre ${ }^{1,2}$, Vincent Bonny ${ }^{1}$, \\ Naïke Bigé ${ }^{1}$, Jean-Luc Baudel ${ }^{1}$, Arnaud Bruneel ${ }^{3}$, Thierry Dupre ${ }^{3}$, Bertrand Guidet ${ }^{1,2,4}$, Eric Maury ${ }^{1,2,4}$ and \\ Hafid Ait-Oufella ${ }^{1,2,5^{*}}$ (D)
}

\begin{abstract}
Background: Vitamin C has potential protective effects through antioxidant and anti-inflammatory properties. However, the effect of vitamin C supplementation on microvascular function and peripheral tissue perfusion in human sepsis remains unknown. We aimed to determine vitamin $C$ effect on microvascular endothelial dysfunction and peripheral tissue perfusion in septic shock patients.
\end{abstract}

Methods: Patients with septic shock were prospectively included after initial resuscitation. Bedside peripheral tissue perfusion and skin microvascular reactivity in response to acetylcholine iontophoresis in the forearm area were measured before and $1 \mathrm{~h}$ after intravenous vitamin C supplementation (40 mg/kg). Norepinephrine dose was not modified during the studied period.

Results: We included 30 patients with septic shock. SOFA score was 11 [8-14], SAPS II was 66 [54-79], and in-hospital mortality was $33 \%$. Half of these patients had vitamin C deficiency at inclusion. Vitamin C supplementation strongly improved microvascular reactivity (AUC 2263 [430-4246] vs 5362 [1744-10585] UI, $p=0.0004$ ). In addition, vitamin C supplementation improved mottling score $(p=0.06)$, finger-tip $(p=0.0003)$ and knee capillary refill time (3.7 [2.6-5.5] vs $2.9[1.9-4.7] \mathrm{s}, p<0.0001)$, as well as and central-to-periphery temperature gradient (6.1 [4.9-7.4] vs 4.6 [3.4-7.0] ${ }^{\circ} \mathrm{C}$, $p<0.0001)$. The beneficial effects of vitamin $C$ were observed both in patients with or without vitamin $C$ deficiency.

Conclusion: In septic shock patients being resuscitated, vitamin C supplementation improved peripheral tissue perfusion and microvascular reactivity whatever plasma levels of vitamin C. ClinicalTrials.gov Identifier: NCT04778605 registered 26 January 2021.

Keywords: Sepsis, Vitamin C, Mottling, Tissue perfusion, Microvascular function

\footnotetext{
*Correspondence: hafid.aitoufella@aphp.fr

${ }^{1}$ Assistance Publique - Hôpitaux de Paris (AP-HP), Hôpital Saint-Antoine,

Service de réanimation médicale, 184 rue du Faubourg Saint-Antoine,

75571 Paris Cedex 12, France

Full list of author information is available at the end of the article
}

\section{Introduction}

Sepsis is a common and life-threatening condition that develops in response to bacterial injury. Around 50 millions of incident cases of sepsis are recorded worldwide every year. In the USA, around 535 cases of sepsis occur annually per 100,000 people, accounting for more than USD 23 billion in annual US hospital expenditures [1]. Despite improvement in early resuscitation, sepsisrelated disability and mortality remain unacceptably 
high [2]. Therefore, in association with symptomatic correction of acute circulatory failure and infection source control, there is urgent need for novel therapies to limit sepsis-induced tissue damage and organ failure.

Sepsis pathophysiology is complex, with immune response dysregulation, coagulation activation and oxidative burst affecting cardiac and endothelial cell function, resulting in impaired microvascular blood flow, tissue hypoperfusion and ultimately life-threatening organ failure [3]. Several studies have reported that the severity [4] and persistence [5] of microvascular blood flow alterations are closely correlated with patient prognosis. At bedside, impaired peripheral tissue perfusion evaluated using mottling score [6], capillary refill time [7] or temperature gradient [8] has been associated with poor outcome.

Recently, vitamin C supplementation (Ascorbic acid) has been proposed as a potential "pleiotropic" form of therapy, interacting with multiple pathologic pathways in sepsis. Several potential beneficial effects of vitamin $C$ have been reported in both animal $[9,10]$ and human studies [11], including (1) antioxidant properties (scavenging of reactive oxygen species) [12, 13], (2) downregulation of pro-inflammatory gene expression (cytokines, chemokines), (3) restoration of immune cell activity [14-16], (4) downregulation of coagulation gene expression [17]. Experimental studies have also reported that vitamin $C$ could modulate endothelial function $[18,19]$. However, the in vivo effect of vitamin $\mathrm{C}$ on microvascular blood flow and tissue perfusion in sepsis patients with severe infections has never been investigated before.

In this study, we aimed to prospectively explore the effects of vitamin $C$ supplementation on both endothelial-dependent microvascular reactivity and bedside peripheral tissue perfusion in septic shock patients.

\section{Materiel and methods \\ Included patients}

We conducted a prospective study in an 18-bed intensive care unit (ICU) in a tertiary teaching hospital. During a 6-month period, patients older than 18 years admitted for septic shock were included. Septic shock was defined according to the Third International Consensus Definitions for Sepsis and Septic Shock [20]. We included resuscitated patients within the first $24 \mathrm{~h}$ of vasopressor initiation. Exclusion criteria were pregnancy, forearm skin lesions, important soft tissue edema and agitation.

After initial therapeutic management, including antibiotic administration, fluid infusion $(30 \mathrm{~mL} /$ $\mathrm{kg}$ ) and norepinephrine infusion to maintain a MAP $>65 \mathrm{mmHg}$, as well as infection focus control when available, patients received intravenous (IV) vitamin C (40 mg/kg) over $30 \mathrm{~min}$ [21]. We compared global hemodynamic and tissue perfusion parameters before and $1 \mathrm{~h}$ after vitamin $\mathrm{C}$ supplementation, as well as skin microvascular endothelial reactivity (see below). No intervention was done during microvascular exploration (Unchanged vasopressor dose, no injection of fluid, steroid or inodilator).

\section{Assessment of skin microcirculation reactivity}

The skin microvascular reactivity was measured in the forearm area by transdermal iontophoresis of acetylcholine (Ach) [22]. This non-invasive technique allows local transfer of Ach across the skin, which produces vasomotor action on subcutaneous capillaries [23, 24]. Ach solution and a weak electrical current are applied onto the skin, creating local differences in electrical potential and active migration of ions and molecules bearing a net electrical charge through epithelial layers. The direction and speed of migration can be adjusted using polarity and the current's magnitude. The total amount of Ach delivered into the skin is related to the current and duration of application (i.e., electrical charge). Acetylcholine acts as an endothelium-dependent vasodilator [25], which induces the production of nitric oxide (NO) after stimulation of the endothelial NO-Synthase. Next, NO induces smooth muscle cells relaxation by activating guanylate cyclase that is responsible for vasodilation and increased blood flow.

The iontophoresis drug delivery chamber was attached to the flexor surface of the non-dominant forearm. The negative lead of the current source was attached to the drug delivery chamber, and the positive lead (i.e., reference electrode) to a conductive hydrogel pad fixed onto the wrist. After measurement of baseline blood flow for $60 \mathrm{~s}$, three successive applications of Ach were made, every $60 \mathrm{~s}$, using anodal current $(0.12 \mathrm{~mA}$ for $12 \mathrm{~s}$ each). The drug delivery chamber was loaded with $80 \mu \mathrm{L}$ of Ach $\left(\right.$ Miochol $\left.^{\circledR}\right)$. Variations of blood flow in the skin were assessed by Laser-Doppler Flowmetry technique. A Laser-Doppler Flowmeter probe (Periflux 5000, Perimed), embedded within a heating drug delivery chamber, was used in combination with a current-controlled delivery device (Perilont, Perimed). Laser-Doppler Flowmeter signals were recorded continuously using an interfaced computer with acquisition software (Perisoft, Perimed).

Baseline blood flow (BF) and area-under-the-curve (AUC) of BF recorded during a standardized 10-min period were recorded (Additional file 1). Skin blood flow monitoring and analysis were performed by an independent physician who did not participate in patient care. 


\section{Data collection}

Patients' characteristics were prospectively collected: age, sex, previous chronic illness, severity of illness evaluated by the Sequential Organ Failure Assessment score (SOFA score) at inclusion [26], source of sepsis, mode of mechanical ventilation, and vasopressor dose. Biological parameters, global hemodynamic parameters [mean arterial pressure (MAP), heart rate (HR)] and cardiac output measured using echocardiography were recorded at 2 time points. In addition, several tissue perfusion parameters were collected at baseline and $1 \mathrm{~h}$ after vitamin $\mathrm{C}$ supplementation: arterial lactate level, index and knee capillary refill time and mottling score, skin temperature and central-skin temperature gradient.

\section{Plasma levels of vitamin C}

Vitamin C plasma levels were measured by a highperformance liquid chromatography (HPLC) method adapted from Speek et al. [27]. Briefly, heparinized plasma is stabilized by diluting samples $(1 / 10 ; \mathrm{v} / \mathrm{v})$ with $5 \%(\mathrm{w} / \mathrm{v})$ metaphosphoric acid solution. The samples remain frozen at $-80{ }^{\circ} \mathrm{C}$ until assayed. After alcalinization of samples with sodium acetate $4.5 \mathrm{mM}$ (respectively $1 \mathrm{~mL}$ and $0.2 \mathrm{~mL}$ ) and action of ascorbate oxidase (25 $\mu \mathrm{L}$ solution $62 \mathrm{U} / \mathrm{mL}$ in $\mathrm{Na} \mathrm{H}_{2} \mathrm{PO}_{4} 4 \mathrm{mM} \mathrm{pH}$ 5.6; $5 \mathrm{~min}$ at $37{ }^{\circ} \mathrm{C}$ ), the total vitamin $\mathrm{C}$ of the sample is converted into acid L-dehydroascorbate. This compound is derivatized with ortho-phenylenediamine (300 $\mu \mathrm{L}$ OPDA $100 \mathrm{mM}$-water solution, $30 \mathrm{~min} 37^{\circ} \mathrm{C}$ ) giving a fluorescent quinoxaline. The vitamin $\mathrm{C}$ assay is performed by HPLC in reverse phase with fluorimetric detection. The column is an Intersil C18 ODS2 $5 \mu \mathrm{M} 4.6 \times 150 \mathrm{~mm}$. The mobile phase (H2PO4 $50 \mathrm{mM} /$ methanol $(500 / 214 ; \mathrm{v} / \mathrm{v}) \mathrm{pH} 7.4)$ flow is $1.15 \mathrm{~mL} / \mathrm{min}$ and the injection volume $20 \mu \mathrm{L}$. The excitation is done at $346 \mathrm{~nm}$ and emission at $424 \mathrm{~nm}$. All the reagents are from Sigma-Aldrich, the column is from Interchim, and the HPLC system is a Summit Dionex-Thermo.

\section{Statistics}

Continuous variables were presented as median and 25th-75th interquartile ranges (IQRs). Discrete variables were presented as percentages. Comparisons before and after vitamin $C$ injection were made with a paired non-parametric test. Statistical analysis and graphical representations were performed using GraphPad Prism 8.4.1 software (Graph Pad Software Inc., La Jolla, CA). A two-sided $p$ value of less than 0.05 was considered statistically significant.

\section{Ethics}

The protocol was approved by an institution's ethical committee-Comité de Protection des Personnes (CPP Ile de France France, 2019-A03199-48). All patients or their families gave their consent for the study (ClinicalTrials.gov Identifier: NCT04778605).

\section{Result}

\section{Characteristics of included patients}

During the study period, 30 septic shock patients were included. Median age was 67 [57-74] years with a higher proportion of men (70\%). The main sources of infection were respiratory (43\%) and abdominal (33\%). Included patients had severe disease with high SOFA scores (11 [8-14]), high SAPS II (66 [54-79]) and frequent organ support therapy such as invasive mechanical ventilation (67\%). In-ICU mortality was $33 \%(N=10 / 30)$ (Table 1$)$. Global hemodynamic and tissue perfusion parameters were measured after initial resuscitation. All patients received crystalloids $(2.5[2.1,3.2] \mathrm{L})$ and norepinephrine to maintain MAP > $65 \mathrm{mmHg}$ (dose 0.6 [0.3-1.2] $\mu \mathrm{g} / \mathrm{kg} / \mathrm{min})$.

Biological parameters of included patients are depicted in Table 1.

\section{Microvascular blood flow parameters}

Endothelial-dependent microvascular reactivity was measured in the forearm area after acetylcholine challenge before and $1 \mathrm{~h}$ after vitamin $\mathrm{C}$ administration. We observed that skin microvascular reactivity, evaluated using the area under the curve (AUC) during a 10-min monitoring period, strongly increased after vitamin C supplementation (AUC 2263 [430-4246] vs 5362 [1744-10585] UI, $p=0.0004$ ) (Fig. 1A, B). Vitamin C improved microvascular reactivity in patients with and without peripheral tissue hypoperfusion (Additional file 2).

\section{Global hemodynamic and tissue perfusion parameters}

Parameters were recorded after initial resuscitation, before and $1 \mathrm{~h}$ after vitamin $\mathrm{C}$ supplementation. Following vitamin $\mathrm{C}$ infusion, cardiac output significantly decreased $(4.1(3.3-4.5)$ vs $4(3.1-4.3) \mathrm{L} / \mathrm{min}$, $p=0.0376)$ and MAP tended to increase (71 (66-75) vs $72(66-77) \mathrm{mmHg} ; p=0.07)$ despite no change in vasopressor dose $(0.60[0.30-1.10]$ vs $0.60[0.30-1.20] \mu \mathrm{g} /$ $\mathrm{kg} / \mathrm{min} ; p=0.46$ ) (Table 2). Interestingly, we observed that vitamin $C$ supplementation quickly improved peripheral tissue perfusion with a trend to a decrease of mottling score $(p=0.06)$, and a significant decrease in finger-tip CRT $(2.1(1.7-3.5)$ vs $2(1.2-3)$ s, $p=0.0003)$, Knee CRT (3.7 (2.6-5.5) vs $2.9(1.9-4.7)$ s, $p<0.0001)$, 
Table 1 General characteristics of included patients

\begin{tabular}{ll}
\hline Patients' characteristics & $\boldsymbol{n}(\%)$ or Med. [IQR] \\
\hline Age & $67[57-74]$ \\
Body mass index $\left(\mathrm{kg} / \mathrm{m}^{2}\right)$ & $22[20-26]$ \\
Male gender & $21(70)$ \\
Simplified Acute Physiology Score 2 & $66[54-79]$ \\
Sequential Organ Failure Assessment & $11[8-14]$ \\
Comorbidities & \\
Diabetes & $7(23)$ \\
Hypertension & $14(46)$ \\
Cardiovascular disease & $10(33)$ \\
Tobacco use & $6(20)$ \\
Cirrhosis & $3(10)$ \\
Cancer/hematologic malignancies & $5(17)$ \\
Septic shock sources & \\
Lung & $13(43)$ \\
Abdomen & $10(33)$ \\
Urinary tract & $3(10)$ \\
Catheter & $2(7)$ \\
Others & $2(7)$ \\
Organ support therapy & \\
Invasive mechanical ventilation & $20(67)$ \\
Norepinephrine dose $(\mu g / k g / m i n)$ & $0.6[0.3-1.2]$ \\
Crystalloid infusion prior vitamin C (L) & $2.50[2.10-3.20]$ \\
Hydrocortisone & $12(40)$ \\
Biological parameters at inclusion & \\
Leucocytes (Giga/L) & $11(1.5-24)$ \\
Hemoglobin (g/dL) & $10.6(8.3-15.2)$ \\
Platelets (Giga/L) & $132(50-208)$ \\
Serum creatinine $(\mu m o l / L)$ & $119(83-182)$ \\
Procalcitonin (ng/mL) & $12(2.7-30)$ \\
Bicarbonate (mmol/L) & $21(17-24)$ \\
Arterial lactate $(\mathrm{mmol} / \mathrm{L})$ & $3.9(2.8-5.1)$ \\
Protidemia (g/L) & $57(46-63)$ \\
\hline &
\end{tabular}

skin temperature and central-to-skin temperature gradient $\left(6.1(4.9-7.4)\right.$ vs $\left.4.6(3.4-7.0){ }^{\circ} \mathrm{C}, p<0.0001\right)$ (Fig. 2C, Table 2).

\section{Tissue perfusion parameters and microvascular} parameters according to plasma levels of vitamin C

Plasma levels of vitamin $C$ were measured in 24/30 septic shock patients at admission. Half of them $(N=12 / 24)$ had vitamin $\mathrm{C}$ deficiency ( $<5 \mathrm{mg} / \mathrm{L},[28]$ ) (Fig. 2A). We did not observe any difference between no-deficiency and deficiency groups in terms of age, gender and comorbidity, but time between hospital admission and ICU admission was longer in deficiency group patients
(2 [1-5] vs 18 [2-39] days, $p=0.03)$. SOFA and SAPS II were not different between groups, but vasopressor doses trended to be lower in the vitamin C-deficient group (0.6 $[0.2-0.7] \mu \mathrm{g} / \mathrm{kg} / \mathrm{min})$ vs $1.1[0.4-1.4] \mu \mathrm{g} / \mathrm{kg} / \mathrm{min}, p=0.06)$ (Additional file 3).

We found that vitamin $C$ supplementation significantly improved microvascular reactivity in patients with and without vitamin $\mathrm{C}$ deficiency (Fig. 2B), as well as bedside evaluated peripheral tissue perfusion (Table 3). Unexpectedly, we observed a significant positive correlation between baseline vitamin $C$ levels and variations of endothelial response after supplementation $(r=0.64$, $p=0.009)$; in other words, the higher the baseline vitamin $C$ level, the higher the increase in blood flow after vitamin $\mathrm{C}$ supplementation (Additional file 4).

\section{Discussion}

Our study prospectively investigated the impact of vitamin $C$ infusion on microvascular function in septic shock patients. We found that vitamin $\mathrm{C}$ supplementation quickly improved microvascular reactivity and peripheral tissue perfusion, a benefit observed in patients with or without vitamin $\mathrm{C}$ deficiency.

Vitamin C supplementation was performed after initial resuscitation within the first $24 \mathrm{~h}$ of ICU admission. First, we observed that vitamin $\mathrm{C}$ trended to increase mean arterial pressure. Such effect may be due to the pleiotropic activity of vitamin $\mathrm{C}$ which promotes both the transformation of dopamine into norepinephrine and the endogenous catecholamine synthesis [29]. We found that vitamin $\mathrm{C}$ strongly increased skin microvascular blood flow after acetylcholine challenge, supporting an improvement in endothelial-dependent microvascular function. This finding is of great interest because microvascular reactivity is highly correlated with both septic shock severity and outcome: The lower the reactivity, the higher the mortality [30]. Acetylcholine specifically targets endothelial cells and promotes NO release, inducing vascular smooth muscle relaxation and in fine vasodilatation [22]. The beneficial effects of vitamin $\mathrm{C}$ on endothelial and nitric oxide dependent vasodilation have also been previously observed in patients with chronic endothelial dysfunction due to atherosclerosis [31], hypertension [31] or diabetes [32]. Such rapid effect observed one hour after vitamin $\mathrm{C}$ injection may be mediated by increased NO availability, either through enhanced synthesis mediated by $\mathrm{BH} 4$ recycling, direct reduction of nitrite to $\mathrm{NO}$, release of $\mathrm{NO}$ from nitrosothiols, or by scavenging superoxide that would otherwise react with $\mathrm{NO}$ to form peroxynitrite [33]. Vitamin $\mathrm{C}$ may also limit $\mathrm{BH} 4$ oxidation, a key endothelial NOS cofactor [34]. Other protective effects of vitamin $\mathrm{C}$ on endothelial cell biology have been reported but these take 

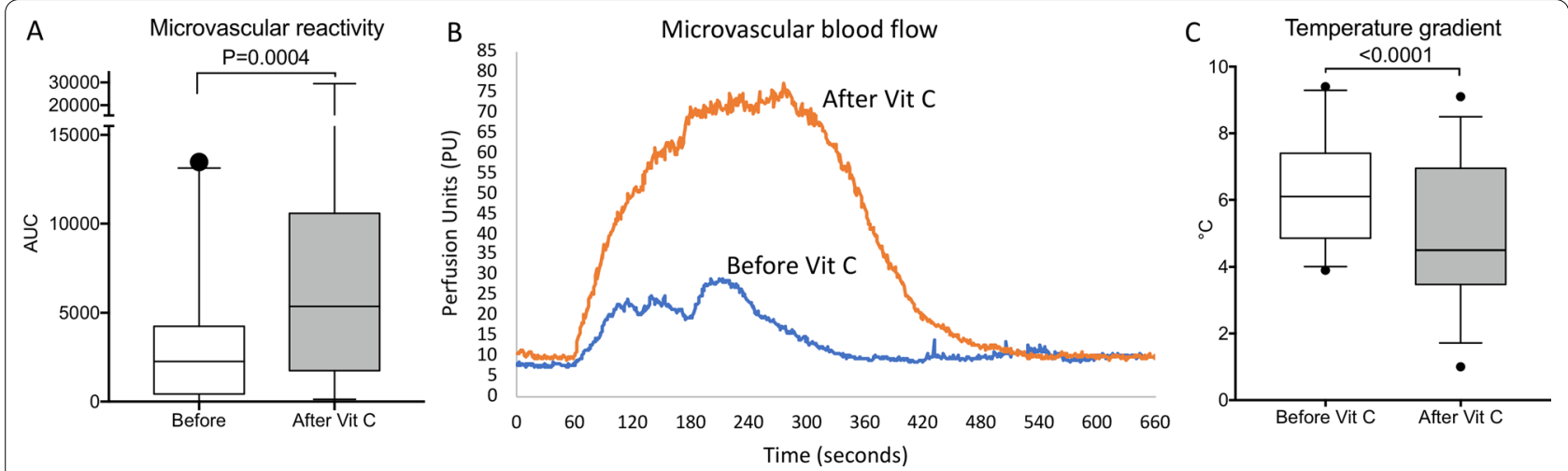

Fig. 1 A Changes of forearm skin microcirculatory reactivity in response to acetylcholine challenge before and after vitamin $C$ supplementation in patients with septic shock. B Example of skin microcirculatory blood flow change in response to acetylcholine iontophoresis before (blue) and after (orange) vitamin C injection. C Central-to-knee skin temperature gradient before and after vitamin C infusion. PU Perfusion units

Table 2 Global hemodynamic and tissue perfusion parameters before and $1 \mathrm{~h}$ after vitamin C infusion

\begin{tabular}{|c|c|c|c|}
\hline Parameters, median (IQR) & $\mathrm{HO}$ & $\mathrm{H} 1$ & $p$ value \\
\hline \multicolumn{4}{|l|}{ Blood pressure $(\mathrm{mmHg})$} \\
\hline Systolic & $107(100-120)$ & $111(102-121)$ & 0.43 \\
\hline Diastolic & $54(51-61)$ & $58(53-62)$ & 0.18 \\
\hline Mean & $71(66-75)$ & $72(66-77)$ & 0.07 \\
\hline Heart rate (/min) & $107(101-111)$ & $107(101-110)$ & 0.67 \\
\hline Mottling score & $1(0-3)$ & $1(0-2)$ & 0.06 \\
\hline \multicolumn{4}{|l|}{ Capillary refill time (s) } \\
\hline Index & $2.1(1.7-3.5)$ & $2(1.2-3)$ & 0.0003 \\
\hline Knee & $3.7(2.6-5.5)$ & $2.9(1.9-4.7)$ & $<0.0001$ \\
\hline Cardiac output (L/min) & $4.1(3.3-4.5)$ & $4(3.1-4.3)$ & 0.0376 \\
\hline Skin temperature & $31.2(30.2-32.3)$ & $32.2(31-33.7)$ & $<0.0001$ \\
\hline Central-to-skin gradient temperature & $6.1(4.9-7.4)$ & $4.6(3.4-7.0)$ & $<0.0001$ \\
\hline Norepinephrine dose ( $\mu \mathrm{g} / \mathrm{kg} \mathrm{min})$ & $0.6(0.3-1.2)$ & $0.6(0.3-1.1)$ & 0.46 \\
\hline
\end{tabular}

Bold was used when $p$ value was $\leq 0.05$
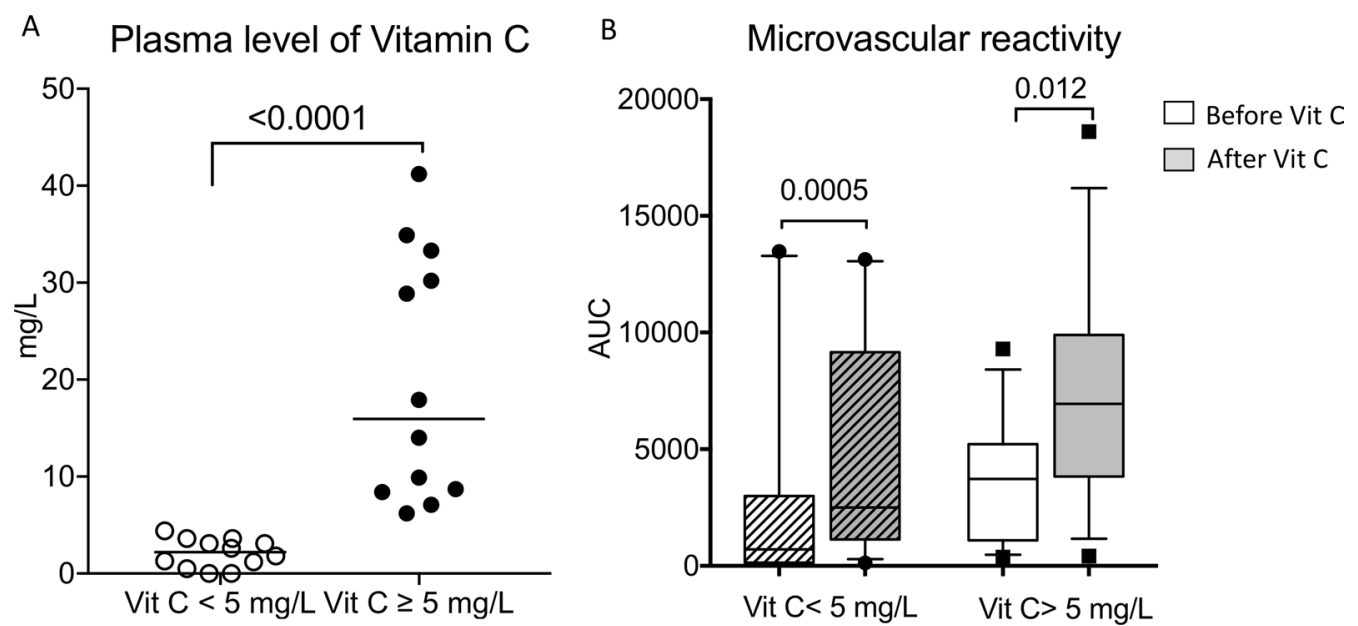

Fig. 2 A plasma levels of vitamin $C$ in patients with and without deficiency in patients with septic shock. $\mathbf{B}$ Changes of microcirculatory reactivity before and after vitamin C supplementation in septic shock patients with and without vitamin C deficiency 
Table 3 Clinical and hemodynamic parameters at admission and $1 \mathrm{~h}$ after vitamin $\mathrm{C}$ infusion of included patients according to vitamin C deficiency

\begin{tabular}{|c|c|c|c|c|c|c|}
\hline \multirow{2}{*}{$\begin{array}{l}\text { Variables, median (IQR) } \\
\text { Vitamin C ( } \mu \mathrm{mol} / \mathrm{L})\end{array}$} & \multicolumn{2}{|l|}{$\mathrm{HO}$} & \multicolumn{2}{|l|}{$\mathrm{H} 1$} & \multicolumn{2}{|c|}{$p$ value $(\mathrm{H} 1 \mathrm{vs} \mathrm{H} 0)$} \\
\hline & $<5 \mu \mathrm{mol} / \mathrm{L}$ & $\geq 5 \mu \mathrm{mol} / \mathrm{L}$ & $<5 \mu \mathrm{mol} / \mathrm{L}$ & $\geq 5 \mu \mathrm{mol} / \mathrm{L}$ & $<5 \mu \mathrm{mol} / \mathrm{L}$ & $\geq 5 \mu \mathrm{mol} / \mathrm{L}$ \\
\hline \multicolumn{7}{|l|}{ Blood pressure $(\mathrm{mmHg})$} \\
\hline Systolic & 103 [100-115] & 108 [101-122] & 109 [96-124] & 110 [101-120] & 0.26 & 0.8 \\
\hline Diastolic & $56[53-64]$ & 53 [45-59] & $58[52-63]$ & $56[51-62]$ & 0.9 & 0.11 \\
\hline Mean & $71[66-77]$ & $67[61-71]$ & 74 [67-79] & $68[64-75]$ & 0.29 & 0.05 \\
\hline Heart rate (/min) & 105 [100-111] & 107 [101-124] & 105 [100-110] & 107 [100-124] & 0.8 & 0.9 \\
\hline Mottling score & $1[0-3]$ & $2[0-3]$ & $1[0-2]$ & $2[0-3]$ & 0.6 & 0.9 \\
\hline \multicolumn{7}{|l|}{ Capillary refill time (s) } \\
\hline Index & $1.8[1.6-3.9]$ & $2.2[1.6-3.1]$ & $1.7[1.2-3.5]$ & $1.9[1.1-2.7]$ & 0.04 & 0.02 \\
\hline Knee & $3.8[2.5-5.8]$ & $4.1[3.4-6]$ & $2.7[1.9-4.7]$ & $3.5[2.3-5.6]$ & 0.001 & 0.005 \\
\hline Cardiac output (L/min) & $3.3[3-4.2]$ & $4.3[3.8-5.2]$ & $3.5[3.1-4.2]$ & $4.3[3-4.7]$ & 0.5 & 0.04 \\
\hline \multicolumn{7}{|l|}{ Temperature $\left({ }^{\circ} \mathrm{C}\right)$} \\
\hline Skin & $31.7[30.2-32.7]$ & $31.2[30.5-32.8]$ & $32[31.1-34.3]$ & $32.2[31.2-33.6]$ & 0.06 & 0.008 \\
\hline Central-to-skin gradient & $6.5[4.8-7.3]$ & $5.3[4.7-6.8]$ & $4.9[3.5-6.9]$ & $4.5[3.3-6.6]$ & 0.06 & 0.001 \\
\hline Norepinephrine infusion ( $\mu \mathrm{g} / \mathrm{kg}$ min) & $0.6[0.2-0.7]$ & $1.1[0.4-1.4]$ & $0.6[0.2-0.7]$ & $1.0[0.4-1.4]$ & 0.9 & 0.5 \\
\hline
\end{tabular}

Bold was used when $p$ value was $\leq 0.05$

longer time to develop. For instance, vitamin $\mathrm{C}$ promotes endothelial cell proliferation, capillary-like structures formation [35, 36] and prevents apoptosis both in vitro [37] and in vivo [38]. Vitamin $C$ treatment limits Intercellular Adhesion Molecule (ICAM)-1 production by human umbilical endothelial cell line [39] and also decreases endothelial glycocalyx shedding in vivo, as assessed by plasma Syndecan-1 levels [40].

In our study, the beneficial effect of vitamin $C$ supplementation was also observed clinically at the bedside with a decrease in mottling score, capillary refill time and temperature gradient, all markers of peripheral tissue perfusion. Mottling extension, which reflects impaired skin microvascular blood flow [41], has been identified as a strong independent predictive factor of mortality in sepsis [42] and septic shock patients [6]. Prolonged CRT measured either on the finger-tip or on the knee area is also associated with poor outcome in studies performed in the emergency ward [43] and the ICU [7]. Some criticisms have been raised about the reproducibility of these bedside parameters, but intra-rater concordance is excellent after standardization and training [44]. Skin temperature (and gradient) changes [8, 45], which were quantified with an accurate and reliable probe, also support the beneficial effect of vitamin $C$ supplementation on peripheral perfusion.

In our cohort, around half of included patients had vitamin $\mathrm{C}$ deficiency, which is in line with previous works reporting that low plasma vitamin $\mathrm{C}$ concentrations are common in critically ill patients, and in particular in patients with sepsis $[46,47]$. Vitamin C levels might be correlated with higher incidence of organ failure in septic patients [48], but in our study, SOFA score was not different patients with and without vitamin $\mathrm{C}$ deficiency. Several combined mechanisms may be responsible for vitamin $\mathrm{C}$ deficiency, such as pro-inflammatory cytokines regulating endothelial sodium-dependent vitamin C transporters activity [49] and increased vitamin $\mathrm{C}$ consumption by leukocyte turnover in the context of sepsis [50]. In our study, vitamin C-deficient group was characterized by longer in-hospital length of stay before ICU admission, with potential decreased vitamin $\mathrm{C}$ intake during hospital stay and also prolonged vitamin $\mathrm{C}$ consumption because of subacute sepsis. The beneficial effects of vitamin $C$ were not restricted to vitamin $C$-deficient patients, since supplementation was also beneficial in septic shock patients without deficiency. The correlation between baseline vitamin $C$ levels and variations of endothelial responses after supplementation was unexpected. Several potential explanations could be proposed: (1) We measured total vitamin $C$ levels but not the oxidized and reduced forms which may have different vascular activity. (2) Recovery of impaired microvascular reactivity in Deficiency group after supplementation may require longer time and/or larger doses. (3) Some confounders between deficiency and no deficiency groups have not been identified.

Overall, the beneficial impact of vitamin $C$ in sepsis patients is still into debate [51]. In a recent meta-analysis including eleven randomized controlled trials and 
more than 1700 patients, high-dose IV vitamin C did not improve short-term survival, but was associated with a significantly shorter duration of vasopressor use, as well as a significantly greater decline in the SOFA score at day 3 [52]. Based on our results, we believe that future trial testing high-dose IV vitamin $\mathrm{C}$ treatment should be proposed in selected septic shock patients with peripheral tissue hypoperfusion, a subset of patients with very poor outcome [53].

Finally, we did not observe any adverse effect after vitamin $C$ injection, confirming previous work showing that pharmacologic ascorbic acid administration is safe. It is noteworthy that Sartor et al. reported that point-of-care blood glucose measurements may become inaccurate after ascorbate injection, since the molecular structures of vitamin C and glucose are somewhat similar [54]

Our study has several limitations. It is a monocentric study, and the results need to be confirmed in a larger population. Nevertheless, we found significative difference despite limited number of patients. Here, we did not include a control group and the improvement of peripheral tissue hypoperfusion could be, at least in part, related to initial resuscitation. However, rapid improvement of endothelial reactivity was unlikely due to fluid alone because in a previous work, we have shown in septic shock patients that saline infusion had no acute impact on endothelial dysfunction [55]. Vitamin C improved vascular parameters in septic shock patients under vasopressor support, but we cannot affirm that the protective effect would be still observed in sepsis patients without vasopressor. Finally, we observed beneficial effect of vitamin $C$ early after infusion but we did not analyze microvascular function and peripheral tissue perfusion at later stages.

\section{Conclusion}

In septic shock patients being resuscitated, vitamin $\mathrm{C}$ supplementation improved microvascular reactivity and peripheral tissue perfusion whatever plasma levels of vitamin C.

\section{Abbreviations}

ACH: Acetylcholine; AUC: Area under the curve; CRT: Capillary refill time; ICU: Intensive care unit; MAP: Mean arterial pressure; SOFA: Sequential organ failure assessment; SAPS II: Simplified acute physiologic score II.

\section{Supplementary Information}

The online version contains supplementary material available at https://doi. org/10.1186/s13054-022-03891-8.

Additional file 1. Figure showing typical recording of microvascular skin blood flow recorded by laser doppler flowmetry baseline and following 3 successive iontophoretic applications of Acetylcholine (Black arrows). AUC, area under curve, SBF, skin blood flow.
Additional file 2. Figure showing changes of microvascular reactivity according to baseline peripheral tissue perfusion in septic shock patients. Vitamin C administration improved microvascular perfusion in patients with (CRT > $2 \mathrm{~s}$ ) and without (CRT > $2 \mathrm{~s}$ ) impaired tissue perfusion. Data are expressed as median and IQRs. AUC for area under the curve and CRT for capillary refill time.

Additional file 3. Table describing general characteristics of patients according to plasma levels of vitamin C. SAPS 2, Simplified Acute Physiology Score 2, SOFA, Sequential Organ Failure Assessment.

Additional file 4. Correlations. A, Correlation between baseline plasma vitamin C levels and baseline Ach-induced microvascular blood flow. B, Correlation between baseline plasma vitamin C levels and variations of Ach-induced microvascular blood flow after supplementation. (Pearson's correlation) Ach, Acetylcholine.

\section{Acknowledgements}

We are indebted to Rozenn Leboursicaud, Amal Abderrahim and Sandra Paco for their help in data extraction and research organization. We are indebted to Assistance Publique-Hôpitaux de Paris staff for his support.

\section{Authors' contributions}

All authors contributed in study concept and design. JRL, LR, TD, AB and $\mathrm{HAO}$ acquired the data. JRL and HAO, EM and BG drafted the manuscript. All authors critically revised the manuscript. JRL, LR and HAO were involved in statistical analysis. All authors read and approved the final manuscript.

\section{Funding}

None.

Availability of data and materials

Not applicable.

\section{Declarations}

\section{Ethics approval and consent to participate}

The protocol was approved by an institution's ethical committee-Comité de Protection des Personnes (CPP Ile de France France, 2019-A03199-48). All patients or their families gave their consent for the study (ClinicalTrials.gov Identifier: NCT04778605). Yes.

Consent for publication

Not applicable.

Competing interests

The authors declare that they have no competing interests.

\section{Author details}

${ }^{1}$ Assistance Publique - Hôpitaux de Paris (AP-HP), Hôpital Saint-Antoine, Service de réanimation médicale, 184 rue du Faubourg Saint-Antoine, 75571 Paris Cedex 12, France. ${ }^{2}$ Sorbonne Université, Paris, France. ${ }^{3}$ Laboratoire de Biochimie, Hôpital Bichat, Université de Paris, Paris, France. ${ }^{4}$ Inserm U1 136, Paris, France. ${ }^{5}$ Centre de Recherche Cardiovasculaire de Paris (PARCC), Paris, France.

Received: 12 November 2021 Accepted: 8 January 2022

Published online: 21 January 2022

\section{References}

1. Fleischmann C, Scherag A, Adhikari NK, Hartog CS, Tsaganos T, Schlattmann P, Angus DC, et al. Assessment of global incidence and mortality of hospital-treated sepsis. Current estimates and limitations. Am J Respir Crit Care Med. 2016;193(3):259-72.

2. Rudd KE, Johnson SC, Agesa KM, Shackelford KA, Tsoi D, Kievlan DR, Colombara DV, et al. Global, regional, and national sepsis incidence and mortality, 1990-2017: analysis for the Global Burden of Disease Study. Lancet. 2020;395(10219):200-11. 
3. Joffre J, Hellman J, Ince C, Ait-Oufella H. Endothelial responses in sepsis. Am J Respir Crit Care Med. 2020;202(3):361-70.

4. De Backer D, Creteur J, Preiser JC, Dubois MJ, Vincent JL. Microvascular blood flow is altered in patients with sepsis. Am J Respir Crit Care Med. 2002;166(1):98-104.

5. Sakr Y, Dubois MJ, De Backer D, Creteur J, Vincent JL. Persistent microcirculatory alterations are associated with organ failure and death in patients with septic shock. Crit Care Med. 2004;32(9):1825-31.

6. Ait-Oufella H, Lemoinne S, Boelle PY, Galbois A, Baudel JL, Lemant J, Joffre $J$, et al. Mottling score predicts survival in septic shock. Intensive Care Med. 2011;37(5):801-7.

7. Ait-Oufella H, Bige N, Boelle PY, Pichereau C, Alves M, Bertinchamp R, Baudel JL, et al. Capillary refill time exploration during septic shock. Intensive Care Med. 2014:40(7):958-64.

8. Bourcier S, Pichereau C, Boelle PY, Nemlaghi S, Dubee V, Lejour G, Baude $\mathrm{J}$, et al. Toe-to-room temperature gradient correlates with tissue perfusion and predicts outcome in selected critically ill patients with severe infections. Ann Intensive Care. 2016;6(1):63.

9. Armour J, Tyml K, Lidington D, Wilson JX. Ascorbate prevents microvascular dysfunction in the skeletal muscle of the septic rat. J Appl Physiol. 2001;90(3):795-803

10. Tyml K, Li F, Wilson JX. Delayed ascorbate bolus protects against maldistribution of microvascular blood flow in septic rat skeletal muscle. Crit Care Med. 2005;33(8):1823-8.

11. Na W, Shen H, Li Y, Qu D. Hydrocortisone, ascorbic acid, and thiamine (HAT) for sepsis and septic shock: a meta-analysis with sequential trial analysis. J Intensive Care. 2021;9(1):75

12. Wilson JX. Mechanism of action of vitamin C in sepsis: ascorbate modulates redox signaling in endothelium. BioFactors. 2009;35(1):5-13.

13. Peng Y, Kwok KH, Yang PH, Ng SS, Liu J, Wong OG, He ML, et al. Ascorbic acid inhibits ROS production, NF-kappa B activation and prevents ethanol-induced growth retardation and microencephaly. Neuropharmacology. 2005:48(3):426-34

14. Goldschmidt MC, Masin WJ, Brown LR, Wyde PR. The effect of ascorbic acid deficiency on leukocyte phagocytosis and killing of actinomyces viscosus. Int J Vitam Nutr Res. 1988;58(3):326-34

15. Johnston CS, Huang SN. Effect of ascorbic acid nutriture on blood histamine and neutrophil chemotaxis in guinea pigs. J Nutr. 1991;121(1):126-30.

16. Mohammed BM, Fisher BJ, Kraskauskas D, Farkas D, Brophy DF, Fowler AA 3rd, Natarajan R. Vitamin C: a novel regulator of neutrophil extracellular trap formation. Nutrients. 2013;5(8):3131-51.

17. Fisher BJ, Seropian IM, Kraskauskas D, Thakkar JN, Voelkel NF, Fowler AA III, Natarajan R. Ascorbic acid attenuates lipopolysaccharide-induced acute lung injury. Crit Care Med. 2011;39(6):1454-60.

18. Wu F, Wilson JX, Tyml K. Ascorbate inhibits iNOS expression and preserves vasoconstrictor responsiveness in skeletal muscle of septic mice. Am J Physiol Regul Integr Comp Physiol. 2003;285(1):R50-6.

19. Wu F, Wilson JX, Tyml K. Ascorbate protects against impaired arteriolar constriction in sepsis by inhibiting inducible nitric oxide synthase expression. Free Radic Biol Med. 2004;37(8):1282-9.

20. Singer M, Deutschman CS, Seymour CW, Shankar-Hari M, Annane D, Bauer M, Bellomo R, et al. The third international consensus definitions for sepsis and septic shock (Sepsis-3). JAMA. 2016;315(8):801-10.

21. Fowler AA III, Syed AA, Knowlson S, Sculthorpe R, Farthing D, DeWilde $C$, Farthing $C A$, et al. Phase I safety trial of intravenous ascorbic acid in patients with severe sepsis. J Transl Med. 2014;12:32.

22. Debbabi H, Bonnin P, Ducluzeau PH, Leftheriotis G, Levy BI. Noninvasive assessment of endothelial function in the skin microcirculation. Am J Hypertens. 2010;23(5):541-6.

23. Hariri G, Urbina T, Lavillegrand JR, Gasperment M, Mazerand S, Abdelmalek A, Bige N, et al. Exaggerated microvascular vasodilating responses in cirrhotic patients with septic shock. Crit Care Med. 2021;49(4):e404-11.

24. Joffre J, Bourcier S, Hariri G, Miailhe AF, Bige N, Dumas G, Dubee V, et al. Reversible microvascular hyporeactivity to acetylcholine during diabetic ketoacidosis. Crit Care Med. 2018:46(8):e772-8.

25. Furchgott RF, Zawadzki JV. The obligatory role of endothelial cells in the relaxation of arterial smooth muscle by acetylcholine. Nature. 1980;288(5789):373-6.
26. Le Gall JR, Lemeshow S, Saulnier F. A new Simplified Acute Physiology Score (SAPS II) based on a European/North American multicenter study. JAMA. 1993:270(24):2957-63.

27. Speek AJ, Schrijver J, Schreurs WH. Fluorometric determination of total vitamin $\mathrm{C}$ in whole blood by high-performance liquid chromatography with pre-column derivatization. J Chromatogr. 1984;305(1):53-60

28. Breskin MW, Trahms CM, Worthington-Roberts B, Labbe RF, Koslowski B. Supplement use: vitamin intakes and biochemical indexes in 40- to 108-month-old children. J Am Diet Assoc. 1985;85(1):49-56.

29. May JM, Qu ZC, Meredith ME. Mechanisms of ascorbic acid stimulation of norepinephrine synthesis in neuronal cells. Biochem Biophys Res Commun. 2012:426(1):148-52.

30. Bourcier S, Joffre J, Dubee V, Preda G, Baudel JL, Bige N, Leblanc G, et al. Marked regional endothelial dysfunction in mottled skin area in patients with severe infections. Crit Care. 2017;21(1):155.

31. Gokce N, Keaney JF Jr, Frei B, Holbrook M, Olesiak M, Zachariah BJ, Leeuwenburgh C, et al. Long-term ascorbic acid administration reverses endothelial vasomotor dysfunction in patients with coronary artery disease. Circulation. 1999;99(25):3234-40.

32. Tousoulis D, Antoniades C, Vasiliadou C, Kourtellaris P, Koniari K, Marinou $\mathrm{K}$, Charakida $\mathrm{M}$, et al. Effects of atorvastatin and vitamin C on forearm hyperaemic blood flow, asymmentrical dimethylarginine levels and the inflammatory process in patients with type 2 diabetes mellitus. Heart. 2007:93(2):244-6.

33. May JM. How does ascorbic acid prevent endothelial dysfunction? Free Radic Biol Med. 2000;28(9):1421-9.

34. Tyml K, Li F, Wilson JX. Septic impairment of capillary blood flow requires nicotinamide adenine dinucleotide phosphate oxidase but not nitric oxide synthase and is rapidly reversed by ascorbate through an endothelial nitric oxide synthase-dependent mechanism. Crit Care Med. 2008:36(8):2355-62

35. Saeed RW, Peng T, Metz CN. Ascorbic acid blocks the growth inhibitory effect of tumor necrosis factor-alpha on endothelial cells. Exp Biol Med (Maywood). 2003;228(7):855-65.

36. Schor AM, Schor SL, Allen TD. Effects of culture conditions on the proliferation, morphology and migration of bovine aortic endothelial cells. J Cell Sci. 1983;62:267-85.

37. Haendeler J, Zeiher AM, Dimmeler S. Vitamin C and E prevent lipopolysaccharide-induced apoptosis in human endothelial cells by modulation of BCl-2 and Bax. Eur J Pharmacol. 1996;317(2-3):407-11.

38. Rossig L, Hoffmann J, Hugel B, Mallat Z, Haase A, Freyssinet JM, Tedgui $A$, et al. Vitamin $C$ inhibits endothelial cell apoptosis in congestive heart failure. Circulation. 2001;104(18):2182-7.

39. Mo SJ, Son EW, Rhee DK, Pyo S. Modulation of TNF-alpha-induced ICAM-1 expression, $\mathrm{NO}$ and $\mathrm{H}_{2} \mathrm{O}_{2}$ production by alginate, allicin and ascorbic acid in human endothelial cells. Arch Pharm Res. 2003:26(3):244-51.

40. Kashiouris MG, L'Heureux M, Cable CA, Fisher BJ, Leichtle SW, Fowler AA. The emerging role of vitamin $C$ as a treatment for sepsis. Nutrients. 2020:12(2):292.

41. Ait-Oufella H, Bourcier S, Alves M, Galbois A, Baudel JL, Margetis D, Bige $\mathrm{N}$, et al. Alteration of skin perfusion in mottling area during septic shock. Ann Intensive Care. 2013;3(1):31.

42. Preda G, Bourcier S, Joffre J, Boelle PY, Dubee V, Baudel JL, Bige N, et al. Mottling score is associated with 28-day mortality in critically ill patients with sepsis. Minerva Anestesiol. 2017;83(6):664-6.

43. Lara B, Enberg L, Ortega M, Leon P, Kripper C, Aguilera P, Kattan E, et al. Capillary refill time during fluid resuscitation in patients with sepsisrelated hyperlactatemia at the emergency department is related to mortality. PLoS ONE. 2017;12(11):e0188548.

44. Hariri G, Joffre J, Leblanc G, Bonsey M, Lavillegrand JR, Urbina T, Guidet B, et al. Narrative review: clinical assessment of peripheral tissue perfusion in septic shock. Ann Intensive Care. 2019;9(1):37.

45. Lima A, Bakker J. Clinical assessment of peripheral circulation. Curr Opin Crit Care. 2015;21(3):226-31.

46. Schorah CJ, Downing C, Piripitsi A, Gallivan L, Al-Hazaa AH, Sanderson MJ, Bodenham A. Total vitamin C, ascorbic acid, and dehydroascorbic acid concentrations in plasma of critically ill patients. Am J Clin Nutr. 1996;63(5):760-5.

47. Long CL, Maull Kl, Krishnan RS, Laws HL, Geiger JW, Borghesi L, Franks W, et al. Ascorbic acid dynamics in the seriously ill and injured. J Surg Res. 2003;109(2):144-8. 
48. Borrelli E, Roux-Lombard P, Grau GE, Girardin E, Ricou B, Dayer J, Suter PM. Plasma concentrations of cytokines, their soluble receptors, and antioxidant vitamins can predict the development of multiple organ failure in patients at risk. Crit Care Med. 1996;24(3):392-7.

49. Seno T, Inoue N, Matsui K, Ejiri J, Hirata K, Kawashima S, Yokoyama M. Functional expression of sodium-dependent vitamin C transporter 2 in human endothelial cells. J Vasc Res. 2004;41(4):345-51.

50. Oudemans-van Straaten HM, Spoelstra-de Man AM, de Waard MC. Vitamin C revisited. Crit Care. 2014:18(4):460

51. Agarwal A, Hager DN, Sevransky JE. Any role of high-dose vitamin C for septic shock in 2021? Semin Respir Crit Care Med. 2021;42(5):672-82.

52. Sato R, Hasegawa D, Prasitlumkum N, Ueoka M, Nishida K, Takahashi K, Nasu M, et al. Effect of IV high-dose vitamin C on mortality in patients with sepsis: a systematic review and meta-analysis of randomized controlled trials. Crit Care Med. 2021;49:2121-30.

53. Dumas G, Lavillegrand JR, Joffre J, Bige N, de-Moura EB, Baudel JL, Chevret $\mathrm{S}$, et al. Mottling score is a strong predictor of 14-day mortality in septic patients whatever vasopressor doses and other tissue perfusion parameters. Crit Care. 2019;23(1):211.

54. Sartor Z, Kesey J, Dissanaike S. The effects of intravenous vitamin C on point-of-care glucose monitoring. J Burn Care Res. 2015;36(1):50-6.

55. Hariri G, Joffre J, Deryckere S, Bige N, Dumas G, Baudel JL, Maury E, et al. Albumin infusion improves endothelial function in septic shock patients: a pilot study. Intensive Care Med. 2018;44(5):669-71.

\section{Publisher's Note}

Springer Nature remains neutral with regard to jurisdictional claims in published maps and institutional affiliations.

- fast, convenient online submission

- thorough peer review by experienced researchers in your field

- rapid publication on acceptance

- support for research data, including large and complex data types

- gold Open Access which fosters wider collaboration and increased citations

- maximum visibility for your research: over $100 \mathrm{M}$ website views per year

At BMC, research is always in progress.

Learn more biomedcentral.com/submissions 